\title{
Symbiosis between the pea crab Dissodactylus primitivus and its echinoid host Meoma ventricosa: potential consequences for the crab mating system
}

\author{
Colin De Bruyn ${ }^{1,2, *}$, Thierry Rigaud ${ }^{2}$, Bruno David $^{2}$, Chantal De Ridder ${ }^{1}$ \\ ${ }^{1}$ Laboratoire de Biologie Marine (CP 160/15), Université Libre de Bruxelles, 50 avenue F. Roosevelt, 1050 Bruxelles, Belgium \\ ${ }^{2}$ Université de Bourgogne, Laboratoire Biogéosciences, UMR CNRS 5561, 6 boulevard Gabriel, 21000 Dijon, France
}

\begin{abstract}
In many symbioses involving marine crustaceans the nature of the relationships and the population biology remain overlooked, obscuring the understanding of their ecology and evolution. The association between the pea crab Dissodactylus primitivus and the irregular sea urchin Meoma ventricosa was investigated in the Caribbean Sea. The work tested the predictions provided by an evolutionary model, in which host-switching behaviour and polygynandry are expected for the mating system of $D$. primitivus. The crab prevalence (infected sea urchins) and mean burden were high and variable between sites and/or years. All post-metamorphic stages of crabs were found on the host, and no exclusion effect was observed between juvenile and adult crabs. In adults, although a general 1:1 sex ratio was stable over the years, there was no evidence for social monogamy. Adult males occurred more often on host-harbouring non-ovigerous females, suggesting that they search for females available for mating. This assumption was supported by a recolonization experiment showing that the males move between hosts. However, both juveniles and females also moved between hosts, indicating that this behaviour could occur due to causes other than mate searching. D. primitivus inflicts external lesions on $M$. ventricosa teguments. The most severe lesions were associated with a lower gonad volume during spawning, suggesting a reduction in fitness of the host. The demography of $D$. primitivus and the recolonization experiments indicate that the mating system of this crab is the 'pure-search polygynandry of mobile females', but the parasitic nature of the relationship could confound this assumption.
\end{abstract}

KEY WORDS: Parasitism $\cdot$ Mating system $\cdot$ Life cycle $\cdot$ Brachyuran crustaceans $\cdot$ Spatangoids

\section{INTRODUCTION}

The Crustacea constitute a highly diversified group displaying various morphologies and behaviours and occupying a wide variety of habitats in the marine realm. Several groups of crustaceans have independently evolved symbiotic relationships with other macro-invertebrates (Thiel \& Baeza 2001). Here, we consider the term symbiosis in its etymological sense, including parasitism and mutualism (see Douglas 1994). The wide diversity of symbiont lifestyles and the various ecologies and morphologies of the hosts make symbiotic crustaceans particularly relevant for study- ing the evolution of social and mating behaviour in marine invertebrates (Duffy \& Thiel 2007). Baeza \& Thiel (2007) proposed a general framework for an evolutionary model highlighting the relationships between patterns of host usage, mating systems (e.g. monogamy, polygyny, or polyandry) and social structure of symbiotic crustaceans. Mating system, for instance, would depend on host size and/or host availability (reflecting the relative costs of defending a host for 'territorial' symbionts) and on the ability of symbionts to move between hosts (reflecting a potential cost of predation outside the shelter provided by the host). Baeza \& Thiel (2007) and Baeza (2008) have pro- 
vided empirical support for the model, but they claimed that more case studies are needed to strengthen their model.

In crustaceans, as pointed out by Thiel (2000), while many different host-symbiont associations have been described, little is known of the population biology and the nature of the relationship (e.g. mutualism vs. parasitism). Host exploitation will not only depend on mating or social systems of the symbionts, but also on the nature of the symbiotic relationship. For example, a commensal using its host mainly as a shelter or chemical refuge will not exploit it in the same way as a parasite using its host as a food resource. In turn, the nature of host exploitation could influence the social system of the symbiont. For example, in the case of parasitism, host resistance could modulate the number of infecting symbionts, whatever their mating system, and therefore drive their social structure. Thus, knowledge on the nature of the relationship is a prerequisite for understanding symbiosis evolution and ecology.

Within the Crustacea, symbiotic relationships involving brachyuran crabs are quite common. Decapod symbionts belong to 7 families: Porcellanidae, Eumedonidae, Portunidae, Xanthidae, Hapalocarcinidae, Majidae and Pinnotheridae (Gray 1961, Patton 1967, Rinkevich et al. 1991, Ng \& Jeng 1999). In many cases, they use their host as a refuge and are considered commensal. One family, the Pinnotheridae (pea crabs), seems to exclusively comprise symbiotic species (Telford 1982, Narvarte \& Saiz 2004). Pinnotherids have developed a variety of associations. Some species inhabit burrows of polychaetes (Gray 1961) or echiurans (Anker et al. 2005). Others live inside the cloacae of holothuroids (Takeda et al. 1997), in the pharynx of urochordates (Goodbody 1960), in the mantle cavity of molluscs (Christensen \& McDermott 1958, Narvarte \& Saiz 2004), or on the integument of echinoids (Johnson 1952, Gray et al. 1968, Telford 1982, Bell \& Stancyk 1983, Reeves \& Brooks 2001). Among pinnotherids, the species belonging to the Dissodactylus complex live ectosymbiotically with irregular echinoids (Spatangoida and Clypeasteroida) (Griffith 1987a,b) .

Among the pea crab symbioses, that involving the crab Dissodactylus primitivus and the host Meoma ventricosa deserves attention because of its supposed peculiar nature. $D$. primitivus is the only species of the Dissodactylus complex to live on spatangoids (Chesher 1969, Telford 1978a,b, 1982, Pohle \& Telford 1983). The crab has been considered to be an ectoparasite since it browses on echinoid spines and integument, resulting in conspicuous scars (Telford 1982). Therefore, this association contrasts with those involving other Pinnotheridae or Porcellanidae crabs, where symbionts are considered commensal: it seems that those latter crabs use their hosts only as refuge and mating places (Baeza \& Thiel 2000). Most of the life history of the $D$. primitivus $-M$. ventricosa association is unknown, and the question remains open as to the degree to which this association shares characteristics with closely related systems. This state of knowledge differs from that of another group of decapods living on sea urchins, the Porcellanidae, whose life cycles and life histories are better known (Haig 1960, Werding 1983, Baeza \& Thiel 2000, 2003, 2007, Toonen 2004).

The goal of the present study was to increase knowledge of the life history of Dissodactylus primitivus and to test the model of Baeza \& Thiel (2007) in the light of these results. According to this model, we predicted that monogamy is not the mating system for $D$. primitivus, due to the large size of the host compared to the symbiont size. First, we investigated the population structure of the crabs to check if the whole D. primitivus life cycle is spent on its host and to provide insight on its mating system. This was done by analysis of samples collected during the juvenile recruitment period. Second, we investigated the consequences of the feeding behaviour of the crabs on host integument and spines to answer the question whether there is a cost to the host associated with this feeding behaviour. Injuries were described and quantified, and host fitness (fecundity) was compared according to wound status. Third, we investigated crab movement between hosts to test another prediction of the model of Baeza \& Thiel (2007): if not monogamous, D. primitivus males should move between hosts with a high frequency in search of females. This was tested by a recolonization experiment.

\section{MATERIALS AND METHODS}

Collections. Samples were collected along the reef on the north coast of Jamaica (Fig. 1), during the recruitment period of the crab life cycle (i.e. March). Two sampling sites, Western Lagoon (WL) and Eastern Lagoon (EL) were located in Discovery Bay $\left(180^{\circ} 28^{\prime} \mathrm{N}\right.$,

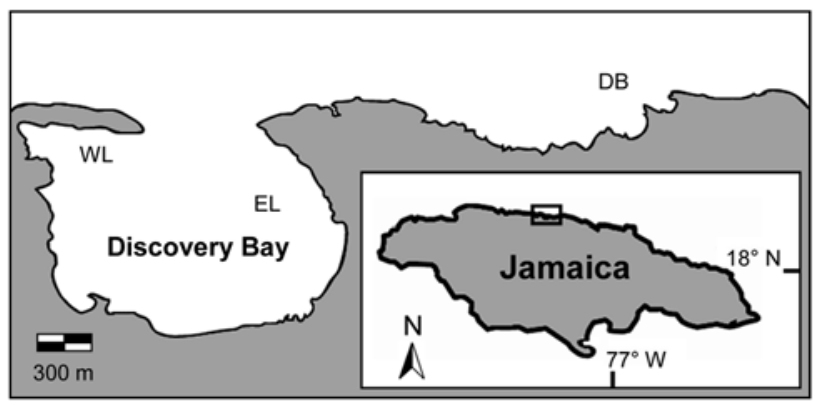

Fig. 1. Sampling sites on the north coast of Jamaica. WL: Western Lagoon; EL: Eastern Lagoon; DB: Dairy Bull 
$\left.77^{\circ} 24^{\prime} \mathrm{W}\right)$, a sheltered area. The third sampling site, Dairy Bull (DB), was outside the bay along the fringing reef $\left(18^{\circ} 28^{\prime} \mathrm{N}, 77^{\circ} 23^{\prime} \mathrm{W}\right.$ ) (Fig. 1). At the 3 sampling sites, the habitat was relatively homogeneous, consisting of large sandy areas adjacent to patches of coral heads (dead or alive) and patches of the seagrass Thalassia testudinum. Further details on the habitats are given in Hammond (1982a) and Gayle \& Woodley (1998).

Meoma ventricosa were haphazardly collected in fine muddy sediment to coarse coral sand at depths ranging from 2 to $4 \mathrm{~m}$ at WL, 5 to $6 \mathrm{~m}$ at EL and 14 to $23 \mathrm{~m}$ at DB. Collections were made by SCUBA diving in March 2005 and 2007 during the early morning. At this time of the day, the echinoids were only lightly burrowed (under 1 to $3 \mathrm{~cm}$ of sand) and easy to detect. Hosts and symbionts were collected together. Each echinoid was carefully placed into a plastic bag that was closed under water by an elastic band. On board, the bags were immersed in basins kept in the shade and were opened upon arrival at the laboratory (no more than 30 min later). Each sea urchin was measured (maximum length and width) with dial callipers. Since these 2 measurements were highly correlated ( $\mathrm{r}=0.95, \mathrm{p}<0.00001)$, only the maximum width was used for analysis. All associated crabs Dissodactylus primitivus were preserved for demographic observations. In total, 211 crabs on 94 sea urchins and 422 crabs on 131 sea urchins were collected in March 2005 and 2007, respectively.

The demography of the crabs, prevalence and burden, were recorded for each site and for each sampling. Prevalence is the percentage of infested hosts at each site, and the mean burden is the mean number of crabs per infected host (Bell 1988). All crabs harvested on each host were counted and measured (maximum cephalothorax width; following Pohle \& Telford 1982), and the gender of each individual was noted. Measurements were taken to the nearest $0.05 \mathrm{~mm}$ using a calibrated ocular micrometer under a stereomicroscope. Males, females and juveniles were counted. Identification was based on morphology: males have a narrow abdomen with the first pair of gonopods highly developed and the second pair reduced; females have a wide abdomen and no gonopods (ovigerous females hold bright orange or pale yellow eggs under their abdomen); and juveniles have undeveloped sexual characters and are generally $<5 \mathrm{~mm}$ in width (Guinot 1979).

Impact on the host. The crabs browse the echinoid integument and appendages, causing injuries (Telford 1982). The relationship between the area of injuries and the mean crab burden was checked in 48 individuals of Meoma ventricosa. In total, 115 injuries were measured (area), described (position on the test) and ranked in 4 categories according to the visible damage to the host. Observations were made under a stereomicroscope. The gonad index was used to investigate a potential negative effect of the injuries on the fitness of $M$. ventricosa. This index corresponds to the ratio between the gonad and the body volume of the sea urchin and is indicative of the fecundity rate (Pearse \& Cameron 1991). For each echinoid, the body and gonad volumes were measured by water displacement in a graduated cylinder (McPherson 1968, Chesher 1969). The gender and the maturity stage of the sea urchins were determined by histological observations of the gonads. The gonads were dehydrated in $100 \%$ ethanol, embedded in paraffin and sectioned into $7 \mu \mathrm{m}$ thick sections by a rotatory microtome. The sections were re-hydrated and mounted with Entellan. Staining was not necessary because of the natural colour of the gonads. Maturity stages were determined according to the descriptions of Chesher (1969) and Nunes \& Jangoux (2004).

Recolonization experiments. To test whether crabs spend some time on the sea floor (outside their sea urchin host), we collected 13 samples of sediment. Each sample consisted of a sediment layer $2 \mathrm{~cm}$ thick taken in a $1000 \mathrm{~cm}^{2}$ quadrat (a rough estimate of the total surface area of a Meoma ventricosa). For comparison, the prevalence of Dissodactylus primitivus was measured on $13 \mathrm{M}$. ventricosa collected in close proximity to each quadrat. The mobility of the crabs was tested at EL at $5 \mathrm{~m}$ water depth and at WL at $2 \mathrm{~m}$ water depth through recolonization experiments following the method described by Thiel et al. (2003). Sixteen $M$. ventricosa were collected at the 2 sites and brought on board. For each individual echinoid, the crabs were removed, counted and their gender (males, females and juveniles) determined. Following this, the echinoids were individually tagged by using an elastic band bearing a nylon thread ending with a labelled float. The elastic band was placed around each individual host. The echinoids devoid of their symbionts were returned to exactly the same place. The time needed to mark each sea urchin did not exceed $10 \mathrm{~min}$. Four days later $(D+4)$, the presence of crabs on the echinoids was checked in situ by SCUBA diving without removing them from the host. Sex of the crabs was not noted. Eight days later $(D+8)$, the echinoids were collected and placed into plastic bags as described above. The newly installed crabs were identified and counted in the laboratory to determine age and sex.

All statistical tests were done using the program JMP 5.0.1.2 (SAS Institute). For continuous data, the normality and the homogeneity of the variances were tested prior to ANOVA or ANCOVA analyses, and were BoxCox transformed if necessary. When normality was impossible to meet, non-parametric tests were made. For 
categorical data comparisons, logistic regression, Chisquared tests, or Fisher exact tests were made.

\section{RESULTS}

\section{Crab populations between sites and years}

Crab Dissodactylus primitivus prevalence was high at all sites (>74\% of Meoma ventricosa were infected), with similar values in 2005 and 2007 (Table 1). In contrast, the mean burden (mean number of crabs per infected host) was variable between the 3 sites (Wilcoxon's tests; 2005: p < 0.0001; 2007: p < 0.001) (Table 1). The maximum burden was 18 crabs per host. The mean burden was also variable between years for DB and EL populations (Table 1).

All crab post-larval stages were found on the host. The youngest stage observed was the 'first crab' (cara-
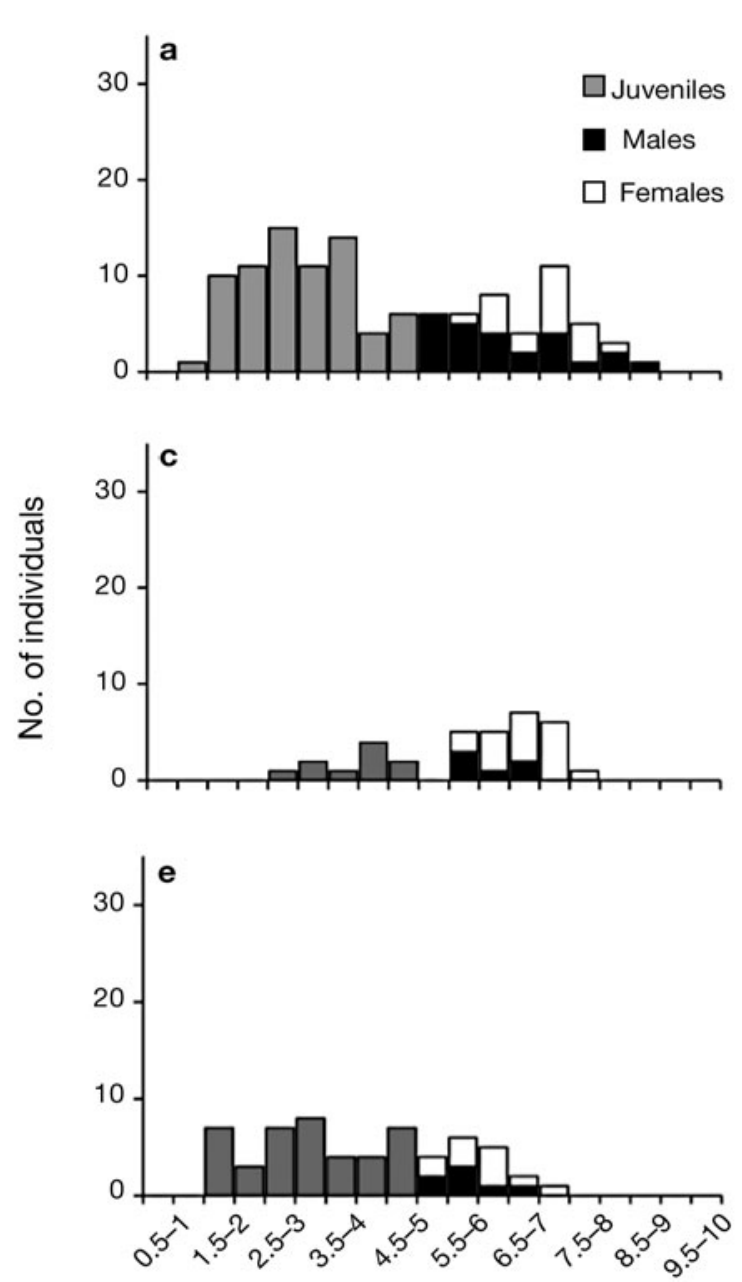

pace width: ca. $0.7 \mathrm{~mm}$ ) (Fig. 2). This stage directly follows the metamorphosis of the last larval stage, i.e. the

Table 1. Dissodactylus primitivus, Meoma ventricosa. Prevalence (\%), with number of investigated hosts in parentheses, and mean burden (95\% confidence interval) of $D$. primitivus crabs living on $M$. ventricosa at the 3 studied sites in 2005 and 2007. p-values for comparisons between years are Fisher's exact test for prevalence and Wilcoxon's test for mean burden.

WL: Western Lagoon; EL: Eastern Lagoon; DB: Dairy Bull

\begin{tabular}{|c|c|c|c|c|}
\hline \multirow[t]{2}{*}{ Sites } & \multirow[t]{2}{*}{ Characteristics } & \multicolumn{2}{|c|}{ - Years } & \multirow[t]{2}{*}{$\mathrm{p}$} \\
\hline & & 2005 & 2007 & \\
\hline \multirow[t]{2}{*}{ WL } & Prevalence & $83(46)$ & $90(49)$ & 0.38 \\
\hline & Mean burden & $2.6(1.9-3.2)$ & $2.4(1.9-2.8)$ & 0.49 \\
\hline \multirow[t]{2}{*}{ EL } & Prevalence & $74(34)$ & $87(63)$ & 0.10 \\
\hline & Mean burden & $1.0(0.7-1.2)$ & $2.7(2.1-3.2)$ & 0.0001 \\
\hline \multirow[t]{2}{*}{ DB } & Prevalence & $93(14)$ & $100(19)$ & 0.42 \\
\hline & Mean burden & $4.1(2.0-6.3)$ & $7.6(5.2-10.0)$ & 0.03 \\
\hline
\end{tabular}

WL

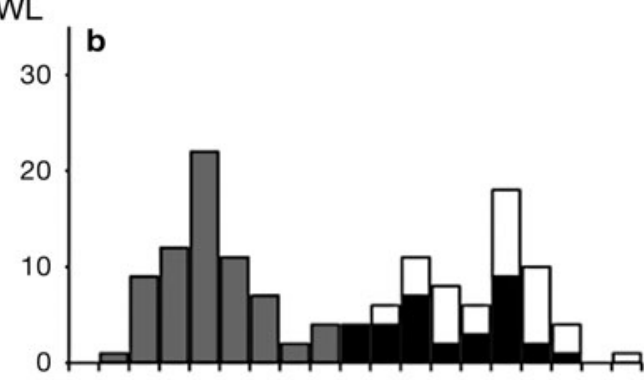

EL
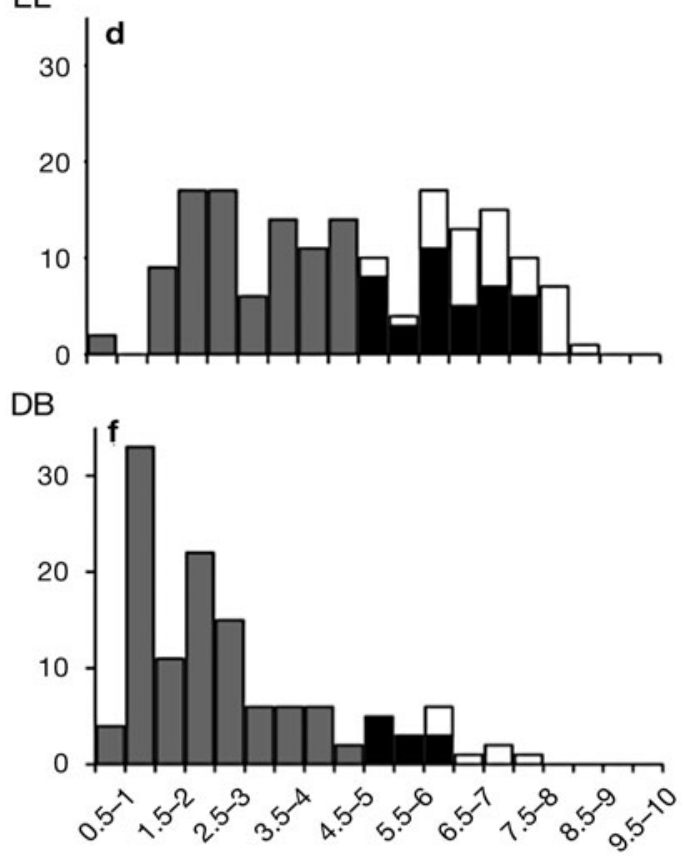

Class size $(\mathrm{mm})$

Fig. 2. Dissodactylus primitivus. Demography of the crabs in the 3 local populations (WL: Western Lagoon; EL: Eastern Lagoon; DB: Dairy Bull) in March 2005 (a,c,e) and 2007 (b,d,f) 
'megalopa' (see Pohle \& Telford 1983). No megalopa stage was found. Juveniles were present at the sites, but their proportion differed between sites and years (Table 2a, Fig. 2). In both years combined, the proportion of juveniles was higher at the outer station (DB) compared to the lagoon stations (WL and EL). The proportion of ovigerous females to total females differed between the 3 sites, but was similar between years (Table 2b). Overall, ovigerous females were more abundant at WL $(53 \%, \mathrm{n}=19$ in 2005 and $64 \%, \mathrm{n}=36$ in 2007) and EL $(61 \%, \mathrm{n}=18$ in 2005 and $37 \%, \mathrm{n}=38$ in 2007) compared to DB $(9 \%, \mathrm{n}=11$ in 2005 and $0 \%$, $\mathrm{n}=7$ in 2007). This observation is consistent with the higher proportion of juveniles at DB. Adults were smaller at DB compared to WL and EL (Fig. 3a), and were smaller in 2005 than in 2007 (Fig. 3b). Juvenile sizes significantly differed between sites and, for DB, between years (Table 3a, Fig. 2). At DB, juveniles were smaller in 2007 than in 2005 (Figs. 2 \& 4).

Table 2. Dissodactylus primitivus. Logistic regression, testing the effects of sampling year and sampling site on the proportion of juvenile crabs (global model: $L-R \chi^{2}=67.97, \mathrm{df}=5, \mathrm{p}<$ 0.0001 ) and the proportion of gravid female crabs (global model: $L-R \chi^{2}=22.34, \mathrm{df}=5, \mathrm{p}=0.0005$ ) living on Meoma ventricosa

\begin{tabular}{|lrrc|}
\hline Source of variation & $\mathrm{df}$ & $L-R \chi^{2}$ & $\mathrm{p}$ \\
\hline Proportion of juvenile crabs & & \\
Year & 1 & 6.90 & 0.009 \\
Site & 2 & 43.86 & $<0.0001$ \\
Year $\times$ Site & 2 & 16.81 & 0.0002 \\
Proportion of adult crabs & & \\
Year & 1 & 1.45 & 0.23 \\
Site & 2 & 18.16 & 0.0001 \\
Year $\times$ Site & 2 & 3.46 & 0.18 \\
\hline
\end{tabular}

Table 3. Dissodactylus primitivus. ANOVA testing the effects of the year of sampling, sampling site and sex on the size of crabs infecting Meoma ventricosa: juvenile crabs (global model: $F_{5,390}=20.61, \mathrm{p}<0.0001$ ) and adult crabs (global model: $\left.F_{4,245}=21.10, \mathrm{p}<0.0001\right)$. To homogenize the variances, Box-Cox transformations of the data were made prior to analyses. The models used minimize the Akaike information criterion

\begin{tabular}{|lrrrr|}
\hline $\begin{array}{l}\text { Source of } \\
\text { variation }\end{array}$ & df & $\begin{array}{r}\text { Sum of } \\
\text { squares }\end{array}$ & $F$ & $p$ \\
\hline Juvenile crabs & & & & \\
Year & 1 & 20.88 & 24.31 & $<0.0001$ \\
Site & 2 & 21.18 & 12.32 & $<0.0001$ \\
Year $\times$ Site & 2 & 13.63 & 7.94 & 0.0004 \\
Error & 390 & 335.05 & & \\
Adult crabs & & & & \\
Year & 1 & 7.86 & 11.10 & 0.001 \\
Site & 2 & 23.89 & 16.87 & $<0.0001$ \\
Sex & 1 & 28.82 & 40.69 & $<0.0001$ \\
Error & 245 & 173.53 & & \\
\hline
\end{tabular}

\section{Host size effects}

The size of Meoma ventricosa (maximum width) was found to be between $67 \mathrm{~mm}$ (minimum size, measured at DB) and $155 \mathrm{~mm}$ (maximum size, measured at WL). It differed according to year $\left(F_{1,218}=17.53, \mathrm{p}<0.0001\right)$ and site $\left(F_{1,218}=28.44, \mathrm{p}<0.0001\right)$ without interaction $\left(F_{1,218}=0.62, \mathrm{p}<0.53\right)$ (global model: $F_{5,218}=16.61, \mathrm{p}<$ 0.0001). Sea urchins were larger in 2005 (ANOVA: $\left.F_{1,260}=15.54, \mathrm{p}=0.0001\right)$ and at WL (ANOVA: $F_{2,91}=$ 12.46, $\mathrm{p}=0.0001$ ). Prevalence was not related to host size, either for juveniles (logistic regression: $\mathrm{df}=1,112$; $\chi^{2}<0.0001, \mathrm{p}=0.99$ ) or for adult crabs (logistic regression: $\left.\mathrm{df}=1,112 ; \chi^{2}<1.42, \mathrm{p}=0.23\right)$. In contrast, the burden of adult crabs was positively correlated with host size (Spearman's correlation: Rho $=0.414, \mathrm{p}=0.003$ ),
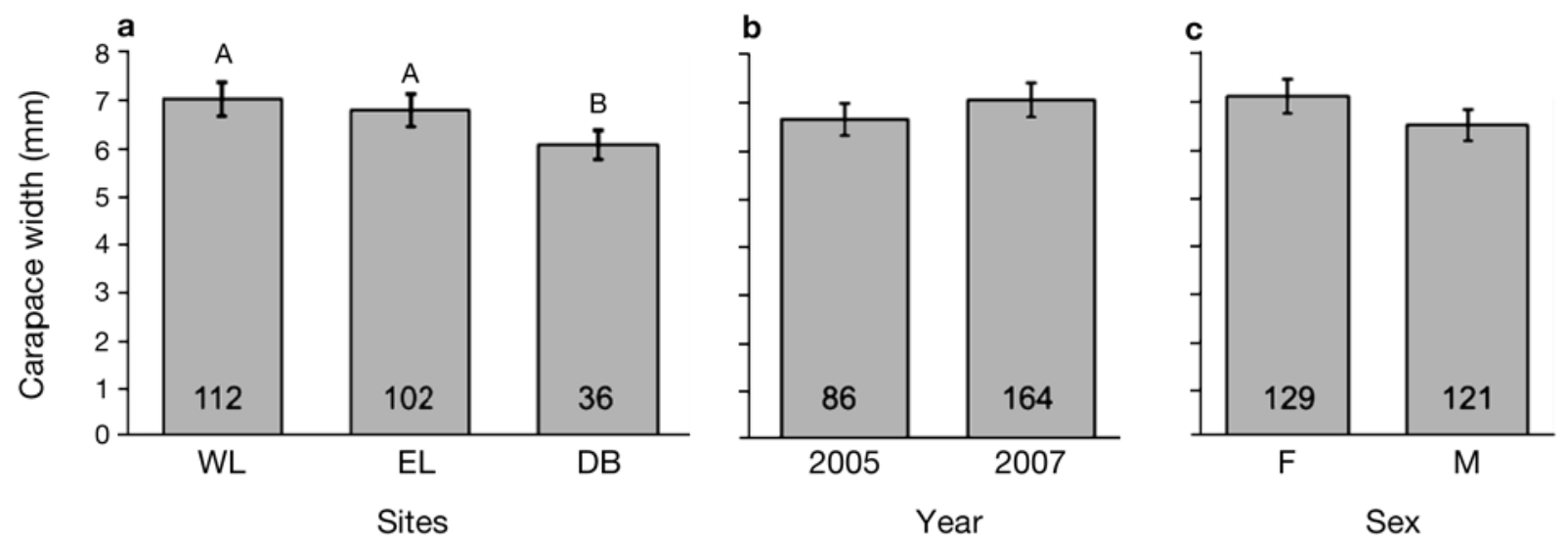

Fig. 3. Dissodactylus primitivus. Size of adult crabs (carapace width, mean \pm SEM) settled on Meoma ventricosa by: (a) sampling site, (b) year of sampling and (c) sex (F: female; M: male). Levels designated by different letters differ significantly according to Tukey honestly significant difference post hoc tests $(\alpha=0.05)$. Numbers in the bars are sample sizes (no. of crabs). Site abbreviations as in Fig. 1 


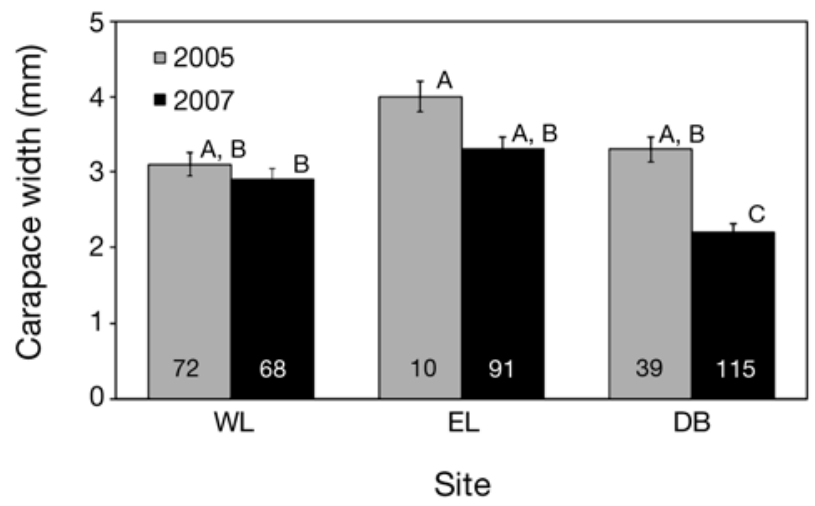

Fig. 4. Dissodactylus primitivus. Size of juvenile crabs (carapace width, mean \pm SEM) settled on Meoma ventricosa by sampling site and year of sampling. Levels designated by different letters differ significantly according to Tukey honestly significant difference post hoc tests $(\alpha=0.05)$. Numbers in the bars are sample sizes (numbers of juveniles). Site abbreviations as in Fig. 1

but not that of juveniles (Spearman's correlation: Rho = $0.25, \mathrm{p}=0.09$ ).

\section{Interactions between crabs}

Males and females occurred in the 3 local populations with a constant sex ratio of $1: 1$, independent of the year (logistic regression including these 2 factors and their interaction, global model: $L-R \chi^{2}=8.92$, df $=5, \mathrm{p}=$ 0.11). Size of adult crabs differed significantly between males and females (males were always smaller than females; Fig. 3c), but also between local populations and years (Table 3b, Fig. 3). About half of the hosts harboured a single adult crab $(51 \%$, total $n=156)$. Heterosexual couples ( 1 male and 1 female) were found on $27 \%$ of the hosts, whereas other combinations (homosexual couples or $>2$ adults) occured in $22 \%$ of the hosts. The proportions of these combinations did not differ significantly between the 3 locations (Pearson's $\chi^{2}$ test: $\left.\mathrm{df}=4,150 ; \mathrm{p}=0.19\right)$. Considering only the heterosexual couples, males were more often found with non-ovigerous females than with ovigerous females (Table 4). There was no correlation between the

Table 4. Dissodactylus primitivus. Presence/absence of male crabs (at least 1 male) on Meoma ventricosa, according to the reproductive status of female crabs present on the same host. The few cases $(n=2)$ where 1 gravid female was accompanied by 1 non-gravid female were counted as 'non-gravid'. Fisher's exact test, 2-tail: $\mathrm{p}=0.04$

\begin{tabular}{|lcc|}
\hline & Male(s) & No male \\
\hline Non-gravid female(s) & 26 & 17 \\
Gravid female(s) & 12 & 22 \\
\hline
\end{tabular}

number of adult and juvenile crabs (Spearman's test: Rho $=0.08, p=0.58$ ). The presence of adults on the host did not impact the presence of juveniles, i.e. there was no inter-generation exclusion effect (Fisher's exact test; 2005: $\mathrm{df}=1,78, \mathrm{p}=0.33 ; 2007: \mathrm{df}=1,110, \mathrm{p}=0.10$ ) (Fig. 5). The presence of heterosexual couples did not affect the number of juveniles either (Wilcoxon's test: $\mathrm{p}=0.17)$.

\section{Injuries and host fitness}

The injuries were categorized into 4 stages according to the degree of visible damage on the appendages and tegument of the sea urchins. Stage 1 injuries corresponded to zones where the spines were cut in their distal or middle part (Fig. 6a). Stage 2 injuries were characterized by more severely attacked spines that were cut at their muscular basis (Fig. 6b). The broken spines were prostrate on the surface of the test or were completely removed. Other appendages (pedicellariae, podia) were also absent from wounds most of the time. At this stage, the epidermis was often naked and had a reddish coloration, as if an inflammatory response had occurred. In Stage 3 (Fig. 6c), the epidermis was completely removed and the test was visible and clean. Stage 4 (Fig. 6d, e) corresponded to injuries in the process of regeneration. Epidermis and appendages regenerate underneath the damaged layer of test. When the dead superficial layer of test is gently removed, a depressed test area covered by a new epidermis with spines in regeneration is seen (Fig. 6e). The loss of this superficial part of the test was observed in the field.

The injuries occurred on both the oral and aboral sides of the sea urchins (ANOVA: $F_{1,86}=2.16, \mathrm{p}=0.15$ ). The mean number of injuries was $2.25 \pm 0.4$ (mean \pm

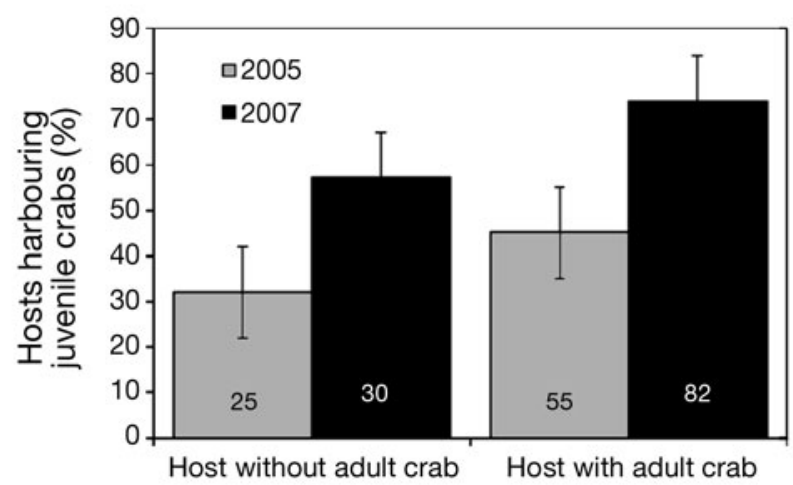

Fig. 5. Meoma ventricosa. Percentage of hosts harbouring juvenile Dissodactylus primitivus crabs (means \pm SEM) according to the presence or absence of adult(s) for 2005 and 2007. Numbers in the bars are sample sizes (numbers of hosts) 

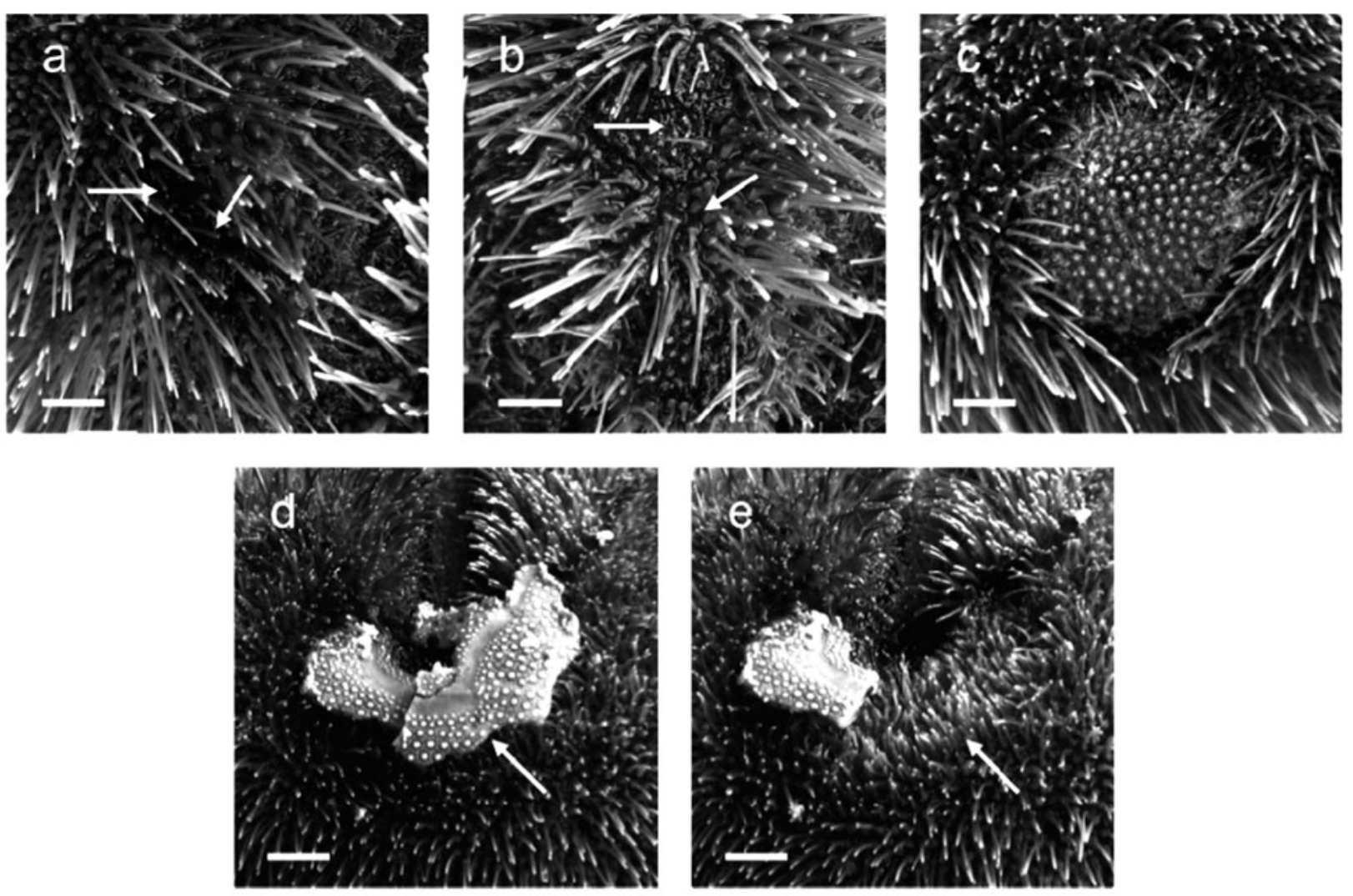

Fig. 6. Meoma ventricosa. Injuries by Dissodactylus primitivus crabs: (a) Stage 1, arrows indicate cut spines; (b) Stage 2, arrows indicate denuded tubercles; (c) Stage 3; (d,e) Stage 4, arrows indicate the loose denuded test (d) and the regenerating tegument and spines underneath after removal of the piece of test (e). Scale bars $=3 \mathrm{~mm}(\mathrm{a}), 4 \mathrm{~mm}(\mathrm{~b}, \mathrm{c})$ and $8 \mathrm{~mm}(\mathrm{~d}, \mathrm{e})$

SEM) per sea urchin $(\mathrm{n}=47)$. The average $( \pm$ SEM) surface area of injuries was $60 \pm 17 \mathrm{~mm}^{2}$ for Stage 1, $42 \pm$ $22 \mathrm{~mm}^{2}$ for Stage 2, $262 \pm 72 \mathrm{~mm}^{2}$ for Stage 3, and $201 \pm$ $29 \mathrm{~mm}^{2}$ for Stage 4 . Neither the number nor the surface of the injuries was correlated with crab burden (Spearman's non-parametric correlation: Rho $=0.01, \mathrm{p}=0.94$ [Fig. 7a] and Rho =0.11, p = 0.45 [Fig. 7b]).

The gonad index of the sea urchins was measured in 20 males and 27 females in 2007 (gender determined on the basis of histological observations). Histological observations also revealed 2 dominant stages of maturity: the 'spent stage' $(\mathrm{n}=17)$ and the 'partly spawned stage' ( $\mathrm{n}=26$ ) (Nunes \& Jangoux 2004). Four gonads corresponded to other stages and were discarded from this analysis. The maturity stages indicate that the samplings (March 2007) were done during the spawning period, corroborating Chesher's (1969) observations. The gonad index did not differ between genders (ANOVA: $F_{1,46}=3.00, \mathrm{p}=0.09$ ) or between maturity stages (ANOVA: $F_{1,41}=1.57, \mathrm{p}=0.22$ ). Considering only echinoids affected by wounds of Stages 3 and/or 4 (indicative of the heaviest potential cost for the host), the wounded echinoids had a lower gonad index compared to the healthy ones (Fig. $7 \mathrm{c}$ ). The final model, including only wound status, minimizes the Akaike information criterion, a parameter that assesses the fit of the model (residual variance) relative to its complexity (number of factors in the model) (Quinn \& Keough 2002).

\section{Crab mobility}

The 13 sediment samples contained no crabs, whereas 12 of the 13 Meoma ventricosa located near these samples carried crabs (Fisher's exact test: $\mathrm{df}=1$, 24; $\mathrm{p}<0.0001)$. The recolonization experiments at the 2 experimental sites (WL and EL) revealed that crabs colonized the cleaned sea urchins. In each replicate, the number of crabs re-colonizing the host was similar between sites, both 4 and $8 \mathrm{~d}$ after cleaning (Fisher's exact test: $\mathrm{p}=0.06$ and $\mathrm{p}=0.26$, respectively) (Table 5). The colonizing crabs were both juveniles and adults. No ovigerous female crabs were found during these experiments, while $24 \%(\mathrm{n}=63)$ and $14 \%(\mathrm{n}=49)$ of hosts harboured ovigerous females at EL and WL, respectively (hosts sampled in 2007). The difference in the proportion of ovigerous females between the recol- 

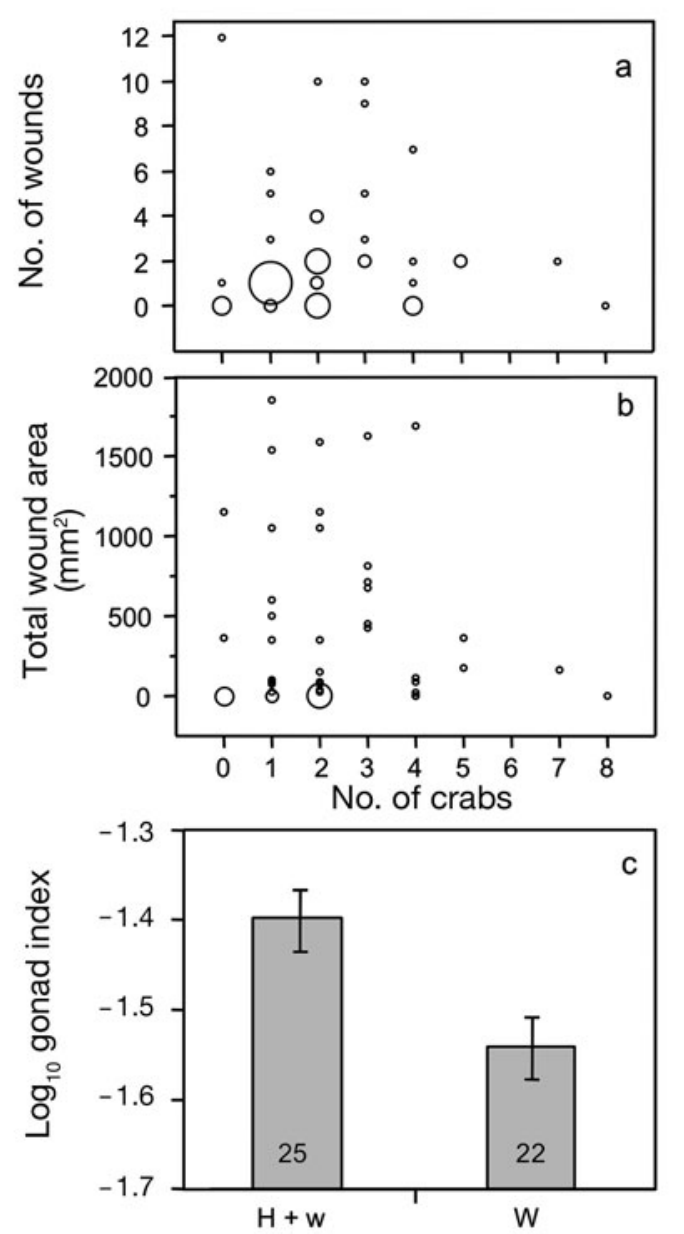

Fig. 7. Meoma ventricosa. Wounds inflicted by different numbers of crabs Dissodactylus primitivus and their effects on the fecundity of $M$. ventricosa. (a) Number of wounds and (b) total wound area by number of crabs (surface of the dots is proportional to the number of data of the same value, the smallest dot representing 1 data point). (c) Gonad index of $M$. ventricosa according to their wound status. $\mathrm{H}+\mathrm{w}$ : healthy sea urchins or with superficial injuries of Stage 1 and/or 2; W: hosts with injuries of Stage 3 and/or 4 (ANOVA: $F_{1,46}=7.32$, $\mathrm{p}=0.01$, statistical model reduced from a model including echinoid sex and wound status as factors, echinoid size as covariates, and their interactions)

Table 5. Dissodactylus primitivus, Meoma ventricosa. Results of the recolonization experiments at Eastern Lagoon (EL) and Western Lagoon (WL); 15 echinoids per site were recaptured at each location. $\mathrm{n} \mathrm{HC}$ : number of $M$. ventricosa colonized and $\mathrm{n} C$ : total number of crabs found on colonized hosts on D +4 and D + 8, i.e. 4 and $8 \mathrm{~d}$ after the start of the experiments. The last column gives the age and sex of crabs found at D +8 . M: male, F: female, J: juvenile

\begin{tabular}{|c|c|c|c|c|c|}
\hline Sites & $\begin{array}{l}-\mathrm{D}- \\
\mathrm{n} \mathrm{HC}\end{array}$ & $4-$ & $\begin{array}{l}-\mathrm{D} \\
\mathrm{n} \mathrm{HC}\end{array}$ & $8-$ & $\begin{array}{c}\text { No. and } \\
\text { sex of crabs }\end{array}$ \\
\hline EL & 9 & 10 & 8 & 12 & $5 \mathrm{M}+3 \mathrm{~F}+4 \mathrm{~J}$ \\
\hline WL & 2 & 3 & 4 & 5 & $0 \mathrm{M}+1 \mathrm{~F}+4 \mathrm{~J}$ \\
\hline
\end{tabular}

onization experiment and the census were significantly different, independent of the site (logistic regression: global model: $\chi^{2}=13.13, \mathrm{df}=3, \mathrm{p}=0.004$; effect 'Experiment': $\chi^{2}=12.27, \mathrm{df}=1, \mathrm{p}=0.0005$; effect 'Site' $\chi^{2}=1.19 \times 10^{-6}, \mathrm{df}=1, \mathrm{p}=0.99$; interaction: $\chi^{2}=$ $1.19 \times 10^{-6}, \mathrm{df}=1, \mathrm{p}=0.99$ ).

\section{DISCUSSION}

\section{Characteristics of the host-parasite relationship}

The symbiosis associating the pinnotherid crab Dissodactylus primitivus with its spatangoid host Meoma ventricosa displayed a high prevalence ranging from 74 to $100 \%$. The prevalence was similar in our 2005 and 2007 collections and also comparable to that observed $30 \mathrm{yr}$ ago by Telford (1978a). The probability of infection was not influenced by host size, but host size influenced the number of colonizing crabs: the larger the host, the more numerous were the adult crabs, probably reflecting a carrying capacity of the host (Baeza \& Thiel 2000, Baeza et al. 2001). For all 3 investigated sites, the crab sex ratio was balanced and stable over both years. Demographic differences between sites were restricted to juveniles and ovigerous females, reflecting slight asynchrony in reproduction. Reproduction appears to occur earlier at the DB site, outside of the bay.

The crab causes injuries by attacking the integument and appendages of its host (Telford 1982). In vitro confirmation of this behaviour was attested by the observation of Stage 1 injuries on 2 healthy echinoids kept for $8 \mathrm{~d}$ in an aquarium in the presence of 5 adult crabs (C. De Bruyn pers. obs.). Nevertheless, the number and area of these injuries were not related to the crab burden. This lack of a relationship could be explained by considering crab movements between hosts and therefore the high instability in time of parasite burden per host. The 2 most advanced stages of injuries corresponded to scars showing the naked test devoid of appendages and epidermis and to regenerating scars, respectively. These stages can potentially induce a cost to the host, because tissue regeneration implies energetic expenditure. Indeed, the gonad size corrected for size (i.e. the gonad index, a proxy for fecundity) was significantly lower in wounded echinoids compared to non-wounded echinoids. Therefore, the crab may have an impact on host fitness as the fecundity of the sea urchin is depressed during the spawning period. These observations should be verified through a long-term study taking into account the different reproduction stages of the echinoid. Because of this cost, Dissodactylus primitivus should be considered a parasite in an ecological and evolutionary sense (Combes 2001). This contrasts with most other known symbioses involving 
crabs and echinoids, which are often considered commensalism. In fact, former studies have shown that symbiotic crabs can acquire food from their hosts in different ways, e.g. in the form of tissue, mucus and faeces (Pearse 1913, Orton 1920, Stauber 1945, Telford 1982, Williams 1984, Valdivia \& Stotz 2006), but very few investigations have addressed the impact of feeding behaviour of the crab on the host. One exception for the Dissodactylus complex is D. mellitae, which induces a putative fecundity cost to its host, the sand dollar Mellita isometra (George \& Boone 2003).

All post-metamorphic stages of Dissodactylus primitivus were present on Meoma ventricosa, juveniles being generally more abundant than adults during the season under investigation (March). In contrast to other symbiotic crabs (Pohle \& Telford 1981, Baeza \& Thiel 2000), the last larval stage of $D$. primitivus (megalopa) was never found on the sea urchins. The presence of the 'first crab' stage on the host indicates that recruitment occurs just after metamorphosis, supporting the hypothesis of Pohle \& Telford (1983). The juvenile crab distribution among hosts was not affected by the presence of adults. This would suggest that there is neither attraction, nor competition for settlement between adults and juveniles of $D$. primitivus. In other associations, competition and exclusion effects are known to occur on overcrowded hosts. For example, in the Dissodactylus mellitae-Mellita quinquiesperforata system, crab growth limits the space available on the host and seems to induce some juveniles to abandon their host for another (Bell 1988). Competition and exclusion effects were also reported for Pinnotheres and Fabia species living in the mantle cavity of molluscs where space is limited (Christensen \& McDermott 1958). In D. primitivus, the small size of the juveniles (10 to 14 times smaller than adults) could facilitate the co-habitation with adults, a phenomenon also made easier by the relatively large size of the host (see 'Results'). Taken together, these findings suggest that $D$. primitivus in the first post-metamorphic stage haphazardly infect $M$. ventricosa.

However, the adult crab distribution was not strictly random, since males were more often found on hosts harbouring non-ovigerous females. This highlights 2 possibilities: (1) the sea urchin could be a mating site for the crabs (males searching females receptive to mating, see below), similar to most symbiotic crabs studied so far (Baeza \& Thiel 2007), or (2) resources (food or space) are limited on the host, as described for other symbioses (e.g. Baeza et al. 2002), and ovigerous (large) females are not keen to share the host. However, the large size of Meoma ventricosa relative to Dissodactylus primitivus does not support the latter possibility.

The recolonization experiment revealed that 'new' crabs rapidly colonize uninfected echinoids and are therefore able to move between hosts. However, no crabs were found in the sediment, suggesting that the movements between hosts are restricted in time and space and that Dissodactylus primitivus does not live outside its host. Movements may occur at night, when the host becomes epifaunal and mobile, and not during the day, when it is infaunal and has reduced mobility (Chesher 1969, Hammond 1982a). Host-switching may be due to an intrinsic high mobility of the crabs. Baeza \& Thiel (2000) mentioned that, in the association between the porcellanid crab Liopetrolisthes mitra and the echinoid Tetrapygus niger, the host-switching behaviour is comparable to the mobility of non-symbiotic species living in patchy microhabitats. Inter-host mobility behaviour has been demonstrated in vitro for some species of crabs of the Dissodactylus complex, in which the mobile crabs were adults (Johnson 1952, Telford 1978b). The travelling crabs observed in our recolonization experiment were both male and female adults, but also large juveniles. This suggests that the youngest crabs are unable to move between hosts. Ovigerous females were not found among travelling crabs, as observed for the symbiotic crab Zebrida adamsii living on several species of sea urchin (Yanagisawa \& Hamaishi 1986). Despite the relatively small sample size for the short-duration experiment, this observation suggests that ovigerous females are likely to stay on their host, i.e. in a protected habitat.

\section{Implications for the mating system of Dissodactylus primitivus}

Recently, a conceptual model has been proposed to predict the mating systems of symbiotic crustaceans (Baeza \& Thiel 2007). Five mating systems could have evolved from strict monogamy to diverse forms of polyandry or polygyny, depending on diverse conditions such as size, complexity and abundance of the hosts and the risk of predation during movements between hosts. For example, host rarity and high predation risk associated with a small host size would lead to monogamy, the host being easy to defend against competitors and an intense search for additional mating being risky for symbionts.

Our study indicates that adult crabs are not found exclusively in heterosexual pairs. Single crabs, homosexual pairs and $>2$ adults can infect an individual host. This contrasts with porcellanid symbiotic crabs and other symbiotic crustaceans for which heterosexual couples are the rule (Hsueh \& Huang 1998, Baeza 2008). This observation rules out social monogamy and mate-guarding as mating systems in Dissodactylus primitivus. In addition, both crab genders are mobile, and hosts are abundant and relatively large compared 
with the crab. Taken together, these observations fit the 'pure-search polygynandry of mobile females' model proposed by Baeza \& Thiel (2007), where both adult males and females move between hosts to find a mate, presumably practicing multiple mating behaviour via active search. However, since the model of Baeza \& Thiel (2007) was designed for commensal relationships, slight modifications may occur due to the parasitic nature of the $D$. primitivus-Meoma ventricosa relationship. Our observation of the co-occurrence of ovigerous and non-ovigerous adult females in populations fits another prediction of this mating system, because breeding asynchrony should reinforce its evolution (Baeza \& Thiel 2007). Due to the presence of embryos hiding genital apertures, ovigerous females are not immediately available for reproduction, while non-ovigerous females are a potential resource for mating. This implies that males searching for a mate are able to distinguish the female status, as proposed by Diesel (1988) for the spider crab Inachus phalangium. In the case of our study, this hypothesis remains to be verified.

However, because of the apparent complexity of the symbiosis, the Dissodactylus primitivus mating system still requires further investigation. Our observations suggest that ovigerous female crabs might be more sedentary and territorial than other individuals. In addition, and more importantly, the parasitic nature of $D$. primitivus may confound some predictions of the model of Baeza \& Thiel (2007). Here, the host is not only a shelter or a mating place, but also a food resource, which could have consequences for the nature of the relationship. For example, host-change behaviour, in addition to mate searching, could also constitute a 'damage avoidance tactic' (Combes 2001), indirectly allowing the host to recover (by tissue regeneration). Such behaviour could stabilize the host population and, subsequently, ensure availabilitiy of food and shelter for the parasite. Another hypothesis is that, owing to the cost induced by the parasite, the host could react to the infection (a kind of 'immune' response), forcing the parasites to move and change their host. Meoma ventricosa is known to produce a dense yellow liquid, which is highly iodic and is supposed to be a toxic repulsive against fish predation (Chesher 1969). Even though we have never observed this liquid in natura around the sea urchins despite very high crab prevalence, we cannot rule out the possibility that this liquid may be produced as a protection against excessive infection. To sum up our findings, crab movement between hosts could be due to mate searching, as proposed by Baeza \& Thiel (2007), but could also be due to characteristics of host-parasite relationships. These hypotheses should be tested experimentally. In addition, and beyond the scope of the present study, D. primitivus is known to settle on another spatangoid, Plagiobrissus grandis, sympatric to $M$. ventricosa but rarer (Telford 1982). It would be important, in order to fully establish the relationship between $D$. primitivus and echinoids, to understand the role played by this second host in the population dynamics and structure of the parasitic crab.

Acknowledgements. We are grateful to the staff of the Discovery Bay Marine Laboratory for providing accommodations and laboratory facilities; a special thanks to Anthony for help during dives. The work was supported by a FRIA grant (to C.D.B.) and FNRS grants (to C.D.B. and C.D.R.). It is a contribution of the Centre Inter-universitaire de Biologie Marine (CBIM and of the groups 'Ecologie Evolutive' and 'Forme, Evolution, Diversité' of the laboratory Biogéosciences. We also thank M. Hendrickx for helpful information on Pinnotheridae and J. Lawrence for a final check of the manuscript.

\section{LITERATURE CITED}

Anker A, Murina GV, Lira C, Caripe JAV, Palmer R, Jeng MS (2005) Macrofauna associated with echiuran burrows: a review with new observations of the innkeeper worm, Ochetostoma erythrogrammon Leuckart and Rüppel, in Venezuela. Zool Stud 44:157-190

Baeza JA (2008) Social monogamy in the shrimp Pontonia margarita, a symbiont of Pinctada mazatlantica, off the Pacific coast of Panama. Mar Biol 153:387-395

Baeza JA, Thiel M (2000) Host use pattern and life history of Liopetrolisthes mitra, a crab associate of the black sea urchin Tetrapygus niger. J Mar Biol Assoc UK 80: 639-645

Baeza JA, Thiel M (2003) Predicting territorial behavior in symbiotic crabs using host characteristics: a comparative study and proposal of a model. Mar Biol 142:93-100

Baeza JA, Thiel M (2007) The mating system of symbiotic crustaceans: a conceptual model based on optimality and ecological constraints. In: Duffy JE, Thiel M (eds) Evolutionary ecology of social and sexual systems. Crustaceans as model organisms. Oxford University Press, Oxford

Baeza JA, Stotz W, Thiel M (2001) Life history of Allopetrolisthes spinifrons, a crab associate of the sea anemone Phymactis clematis. J Mar Biol Assoc UK 81:69-76

Baeza JA, Stotz W, Thiel M (2002) Agonistic behaviour and development of territoriality during ontogeny of the sea anemone dwelling crab Allopetrolisthes Spinifrons (H. Milne Edwards, 1837) (Decapoda: Anomura: Porcellanidae). Mar Freshw Behav Physiol 35:189-202

Bell JL (1988) Distribution and abundance of Dissodactylus mellitae Rathbun (Pinnotheridae) on Mellita quinquiesperforata (Leske) (Echinodermata). J Exp Mar Biol Ecol 117:93-114

Bell JL, Stancyk SE (1983) Population dynamics and reproduction of Dissodactylus mellitae (Brachyura: Pinnotheridae) on its sand dollar host Mellita quinquiesperforata (Echinodermata). PSZN I: Mar Ecol 13:141-149

Chesher RH (1969) Contributions to the biology of Meoma ventricosa (Echinoidea: Spatangoida). Bull Mar Sci 19:72-110

> Christensen AM, McDermott JJ (1958) Life-history and biology of the oyster crab Pinnotheres ostreum Say. Biol Bull 114:146-179

Combes C (2001) The ecology and evolution of intimate interactions. The University of Chicago Press, Chicago, IL

Diesel R (1988) Male-female association in the spider crab 
Inachus phalangium: the influence of female reproductive stage and size. J Crustac Biol 8:63-69

Douglas AE (1994) Symbiotic interactions. Oxford University Press, New York

Duffy JE, Thiel M (eds) (2007) Evolutionary ecology of social and sexual systems. Crustaceans as model organisms. Oxford University Press, Oxford

Gayle PMH, Woodley JD (1998) Discovery Bay, Jamaica. In: Kjerfve B (ed) CARICOMP - Caribbean coral reef, seagrass and mangrove sites. Coastal region and small island papers, No. 3, UNESCO, Paris

George SB, Boone S (2003) The ectosymbiont crab Dissodactylus mellitae-sand dollar Mellita isometra relationship. J Exp Mar Biol Ecol 294:235-255

Goodbody I (1960) Abbreviated development in a pinnotherid crab. Nature 185:704-705

Gray IE (1961) Changes in abundance of the commensal crabs of Chaetopterus. Biol Bull 120:353-359

Gray IE, McCloskey LR, Weihe SC (1968) The commensal crab Dissodactylus mellitae and its reaction to sand dollar host factor. J Elisha Mitchell Sci Soc 84:472-481

Griffith H (1987a) Taxonomy of the genus Dissodactylus (Crustacea: Brachyura: Pinnotheridae) with descriptions of three new species. Bull Mar Sci 40:397-422

Griffith H (1987b) Phylogenetic relationships and evolution in the genus Dissodactylus Smith, 1870 (Crustacea: Brachyura: Pinnotheridae). Can J Zool 65:2292-2310

Guinot D (1979) Morphologie et phylogenèse des brachyoures. Mem Mus Nat Hist Nat (Fr) 112:171-250

Haig J (1960) The Porcellanidae (Crustacea, Anomura) of the eastern Pacific. Allan Hancock Pac Exped 24:1-440

Hammond LD (1982a) Patterns of feeding and activity in deposit-feeding holothurians and echinoids (Echinodermata) from a shallow back-reef lagoon, Discovery Bay, Jamaica. Bull Mar Sci 32:549-571

Hsueh PW, Huang JF (1998) Polyonyx bella, new species (Decapoda: Anomura: Porcellanidae), from Taiwan, with notes on its reproduction and swimming behavior. J Crustac Biol 18:332-336

Johnson I (1952) The demonstration of a 'host factor' in commensal crabs. Trans Kans Acad Sci 55:458-464

McPherson BF (1968) Feeding and oxygen uptake of the tropical sea urchin Eucidaris tribuloides (Lamarck). Biol Bull 135:308-321

Narvarte MA, Saiz MN (2004) Effects of the pinnotherid crab Tumidotheres maculatus on the Tehuelche scallop Aequipecten tehuelchus in the San Matias Gulf, Argentina. Fish Res 67:207-214

Ng PKL, Jeng MS (1999) The brachyuran crabs (Crustacea: Decapoda: Eumedonidae and Portunidae) symbiotic with echinoderms in Taiwan. Zool Stud 38:268-274

Nunes DAC, Jangoux M (2004) Reproductive cycle of the spatangoid echinoid Echinocardium cordatum (Echinodermata) in the southwestern North Sea. Invertebr Reprod Dev 45:41-57

> Orton JH (1920) Mode of feeding and sex-phenomena in the pea crab (Pinnotheres pisum). Nature 106:533-534

Patton WK (1967) Commensal Crustacea. Symposium on Crustacea. J Mar Biol Ass India 3:1228-1243

Pearse AS (1913) On the habits of the crustaceans found in Chætopterus tubes at Woods Hole, Massachusetts. Biol Bull 24:102-114

Editorial responsibility: John Lawrence,

Tampa, Florida, USA
Pearse JS, Cameron RA (1991) Echinodermata: Echinoidea. In: Giese AC, Pearse JS, Pearse VB (eds) Reproduction of marine invertebrates, Vol. VI. Echinoderms and lophophorates. Boxwood Press, Pacific Grove, CA

Pohle G, Telford M (1981) The larval development of Dissodactylus crinitichelis Moreira, 1901 (Brachyura: Pinnotheridae) in laboratory culture. Biol Bull 31:753-773

Pohle G, Telford M (1982) Post-larval growth of Dissodactylus primitivus Bouvier, 1917 (Brachyura: Pinnotheridae) under laboratory conditions. Biol Bull 163:211-224

Pohle G, Telford M (1983) The larval development of Dissodactylus primitivus Bouvier, 1917 (Brachyura: Pinnotheridae) reared in the laboratory. Bull Mar Sci 33:257-273

Quinn GP, Keough MJ (2002) Experimental design and data analysis for biologists. Cambridge University Press, Cambridge

Reeves MN, Brooks WR (2001) Host selection, chemical detection, and protection of the symbiotic pinnotherid crabs Dissodactylus crinitichelis and Clypeasterophilus rugatus associated with echinoderms. Symbiosis 30:239-256

Rinkevich B, Wolodarsky Z, Loya Y (1991) Coral-crab association: a compact domain of a multilevel trophic system. Hydrobiologia 216/217:279-284

Stauber LA (1945) Pinnotheres ostreum, parasitic on the American oyster, Ostrea (Gryphaea) virginica. Biol Bull 88:269-291

> Takeda S, Tamura S, Washio M (1997) Relationship between the pea crab Pinnixa tumida and its endobenthic holothurian host Paracaudina chilensis. Mar Ecol Prog Ser 149:143-154

Telford M (1978a) Post-larval growth in two species of Dissodactylus (Brachyura: Pinnotheridae). Bull Mar Sci 28:645-650

Telford M (1978b) Distribution of two species of Dissodactylus (Brachyura: Pinnotheridae) among their echinoid host populations in Barbados. Bull Mar Sci 28:651-658

Telford M (1982) Echinoderm spine structure, feeding and host relationship of four species of Dissodactylus (Brachyura: Pinnotheridae). Bull Mar Sci 32:584-594

> Thiel M (2000) Population and reproductive biology of two sibling amphipod species from ascidians and sponges. Mar Biol 137:661-674

Thiel M, Baeza JA (2001) Factors affecting the social behaviour of symbiotic Crustacea: a modelling approach. Symbiosis 30:163-190

Thiel M, Zander A, Baeza JA (2003) Movements of the symbiotic crab Liopetrolisthes mitra between its host sea urchin Tetrapygus niger. Bull Mar Sci 72:89-101

Toonen RJ (2004) Genetic evidence of multiple paternity of broods in the intertidal crab Petrolisthes cinctipes. Mar Ecol Prog Ser 270:259-263

Valdivia N, Stotz W (2006) Feeding behavior of the porcellanid crab Allopetrolisthes spinifrons symbiont of the sea anemone Phymactis papillosa. J Crustac Biol 26:308-315

Werding B (1983) Kommensalische Porzellaniden aus der Karibik (Decapoda, Anomura). Crustac Int J Crustac Res 45:1-14

Williams AB (1984) Shrimps, lobsters, and crabs of the Atlantic coast of the eastern United States, Maine to Florida. Smithsonian Institution Press, Washington, DC

Yanagisawa Y, Hamaishi A (1986) Mate acquisition by a solitary crab Zebrida adamsii, a symbiont of the sea urchin. J Ethol 4:153-162

Submitted: April 17, 2008; Accepted: September 10, 2008

Proofs received from author(s): January 16, 2009 